\title{
Chemical Analysis of Archived Stream-Sediment Samples, Alaska
}

Open-File Report 2021-1058 



\section{Chemical Analysis of Archived Stream-Sediment Samples, Alaska}

By Bronwen Wang, George N.D. Case, Mathew Granitto, Keith A. Labay, Nora B. Shew, Andrew D. Ingraham, Zachary C. Bueghly, Jaime S. Azain, Susan M. Karl, and Karen D. Kelley

Open-File Report 2021-1058 


\section{U.S. Geological Survey, Reston, Virginia: 2021}

For more information on the USGS - the Federal source for science about the Earth, its natural and living resources, natural hazards, and the environment—visit https://www.usgs.gov or call 1-888-ASK-USGS.

For an overview of USGS information products, including maps, imagery, and publications, visit https://store.usgs.gov/.

Any use of trade, firm, or product names is for descriptive purposes only and does not imply endorsement by the U.S. Government.

Although this information product, for the most part, is in the public domain, it also may contain copyrighted materials as noted in the text. Permission to reproduce copyrighted items must be secured from the copyright owner.

Suggested citation:

Wang, B., Case, G.N.D., Granitto, M., Labay, K.A., Shew, N.B., Ingraham, A.D., Bueghly, Z.C., Azain, J.S., Karl, S.M., and Kelley, K.D., 2021, Chemical analysis of archived stream-sediment samples, Alaska: U.S. Geological Survey

Open-File Report 2021-1058, 13 p., https://doi.org/10.3133/ofr20211058.

Associated data for this publication:

Wang, B., Case, G. N. D., Granitto, M., Labay, K. A., Shew, N. B., Ingraham, A. D., Bueghly, Z. C., Azain, J. S., Karl, S. M. and Kelley, K. D., 2021, Data from the chemical analysis of archived stream-sediment samples, Alaska: U.S. Geological Survey data release, https://doi.org/10.5066/P9FR1D6Y.

ISSN 2331-1258 (online) 


\section{Contents}

Abstract

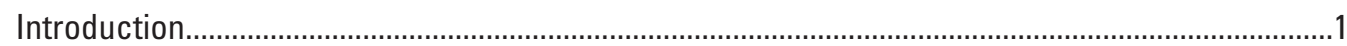

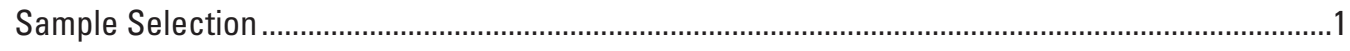

Sample and Quality Control Sample Submittal .....................................................................

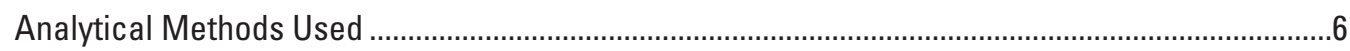

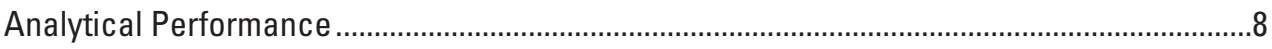

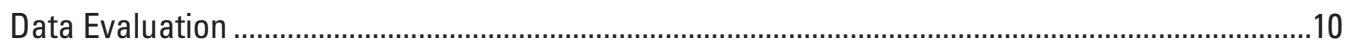

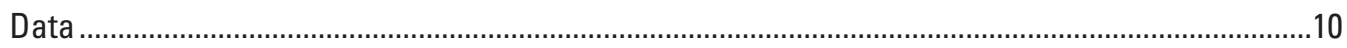

References Cited.................................................................................................................11

Appendix 1. Elemental Concentration Data for Archived Stream Sediment Samples from Alaska Reanalyzed in 2019 and the Accompanying Standard Reference

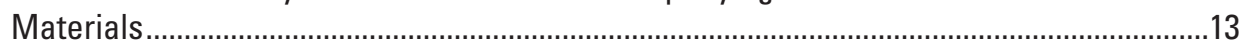

\section{Figure}

1. Map showing the distribution of samples selected for reanalysis based on U.S. Geological Survey mineral prospectivity and transboundary watershed studies, Alaska.....

\section{Tables}

1. Collection agency and pulp characteristics. .3

2. Preferred values for the standard reference materials SAR-L.1 and SAR-M.1 and certified values for SAR-H, SAR-L2, and SAR-M.2...

3. The upper and lower reporting limit and analytical instrument used for elemental determination by element for the fusion method of AGAT Laboratories ..........7

4. Upper and lower reporting limit and analytical instrument used for elemental determination by element for the four-acid method of AGAT Laboratories. 


\section{Conversion Factors}

U.S. customary units to International System of Units

\begin{tabular}{lcc}
\hline Multiply & By & To obtain \\
\hline square mile $\left(\mathrm{mi}^{2}\right)$ & Area & \\
\hline & 2.590 & square kilometer $\left(\mathrm{km}^{2}\right)$ \\
\hline gram $(\mathrm{g})$ & Mass & \\
\hline
\end{tabular}

\section{Datum}

Horizontal coordinate information is referenced to the World Geodetic System 1984 (WGS84).

\section{Abbreviations}

$\begin{array}{ll}\text { AGDB } & \text { Alaska Geochemical Database } \\ \text { CVAAS } & \text { cold vapor atomic absorption spectrometry } \\ \text { ADGGS } & \text { Alaska Division of Geological \& Geophysical Surveys } \\ \text { LIMS } & \text { laboratory information monitoring system } \\ \text { LOD } & \text { lower limit of determination } \\ \text { NAD 83 } & \text { North American Datum of 1983 } \\ \text { NAVD 88 } & \text { North American Vertical Datum of 1988 } \\ \text { NGVD 29 } & \text { National Geodetic Vertical Datum of 1929 } \\ \text { NURE } & \text { National Uranium Resource Evaluation program } \\ \text { ICP-0ES } & \text { inductively coupled plasma-optical emission spectroscopy } \\ \text { ICP-MS } & \text { inductively coupled plasma-mass spectroscopy } \\ \text { ppm } & \text { parts per million } \\ \text { pct } & \text { weight percent } \\ \text { RSD } & \text { relative standard deviation } \\ \text { SRM } & \text { standard reference material } \\ \text { USGS } & \text { U.S. Geological Survey } \\ \text { W-focus area } & \text { areas prospective for tungsten-mineralized rock }\end{array}$




\section{Chemical Symbols}

\begin{tabular}{clcl}
\hline $\begin{array}{c}\text { Element } \\
\text { symbol }\end{array}$ & \multicolumn{1}{c}{$\begin{array}{c}\text { Element } \\
\text { name }\end{array}$} & $\begin{array}{c}\text { Element } \\
\text { symbol }\end{array}$ & $\begin{array}{c}\text { Element } \\
\text { name }\end{array}$ \\
\hline $\mathrm{Ag}$ & Silver & $\mathrm{Mo}$ & Molybdenum \\
$\mathrm{Al}$ & Aluminum & $\mathrm{Nb}$ & Niobium \\
$\mathrm{As}$ & Arsenic & $\mathrm{Nd}$ & Neodymium \\
$\mathrm{B}$ & Boron & $\mathrm{Ni}$ & Nickel \\
$\mathrm{Ba}$ & Barium & $\mathrm{P}$ & Phosphorous \\
$\mathrm{Be}$ & Beryllium & $\mathrm{Pb}$ & Lead \\
$\mathrm{Bi}$ & Bismuth & $\mathrm{Pr}$ & Praseodymium \\
$\mathrm{Ca}$ & Calcium & $\mathrm{Rb}$ & Rubidium \\
$\mathrm{Cd}$ & Cadmium & $\mathrm{S}$ & Sulfur \\
$\mathrm{Ce}$ & Cerium & $\mathrm{Sb}$ & Antimony \\
$\mathrm{Co}$ & Cobalt & $\mathrm{Sc}$ & Scandium \\
$\mathrm{Cr}$ & Chromium & $\mathrm{Se}$ & Selenium \\
$\mathrm{Cs}$ & Cesium & $\mathrm{Si}$ & Silicon \\
$\mathrm{Cu}$ & Copper & $\mathrm{Sm}$ & Samarium \\
$\mathrm{Dy}$ & Dysprosium & $\mathrm{Sn}$ & Tin \\
$\mathrm{Er}$ & Erbium & $\mathrm{Sr}$ & Strontium \\
$\mathrm{Eu}$ & Europium & $\mathrm{Ta}$ & Tantalum \\
$\mathrm{Fe}$ & Iron & $\mathrm{Tb}$ & Terbium \\
$\mathrm{Ga}$ & Gallium & $\mathrm{Te}$ & Tellurium \\
$\mathrm{Gd}$ & Gadolinium & $\mathrm{Th}$ & Thorium \\
$\mathrm{Ge}$ & Germanium & $\mathrm{Ti}$ & Titanium \\
$\mathrm{Hf}$ & Hafnium & $\mathrm{Tl}$ & Thallium \\
$\mathrm{Ho}$ & Holmium & $\mathrm{Tm}$ & Thulium \\
$\mathrm{In}$ & Indium & $\mathrm{U}$ & Uranium \\
$\mathrm{K}$ & Potassium & $\mathrm{V}$ & Vanadium \\
$\mathrm{La}$ & Lanthanum & $\mathrm{W}$ & Tungsten \\
$\mathrm{Li}$ & Lithium & $\mathrm{Y}$ & Yttrium \\
$\mathrm{Lu}$ & Lutetium & $\mathrm{Yb}$ & Ytterbium \\
$\mathrm{Mg}$ & Magnesium & $\mathrm{Zn}$ & Zinc \\
$\mathrm{Mn}$ & Manganese & $\mathrm{Zr}$ & Zirconium \\
\hline & & & \\
\hline
\end{tabular}




\section{Definition of Terms}

Limit of detection The limit of detection (LOD) is the lowest concentration of an analyte that can be statistically distinguished from an analytical blank. The American Chemical Society, the International Union of Pure and Applied Chemistry recommend the limits of detection be three-sigma above the mean average blank: Concentrations three-sigma above the mean average blank have confidence levels of 99.86 percent for normal distributions.

Lower reporting limit The lower reporting limit is defined in various ways in this report. Typically, the lower reporting limit is the LOD multiplied by a factor selected to ensure that analytical variation is not outside specifications set by the analyst, laboratory, or institution. Generally, the calculated accuracy and precision are degraded for concentrations within five times of the lower reporting limit.

Limit of quantitation The limit of quantitation is the concentration 10-sigma greater than the measured average blank concentration. At this concentration, the confidence in the measured result is 30 percent at the 95 -percent probability level. This guideline is set because the risk of false positives or negatives is decreased.

Relative standard deviation The relative standard deviation (RSD) is a statistical calculation used to assess the precision of an analytical method. The RSD for an analyte is calculated by dividing the standard deviation by the mean and multiplying by 100 .

Reported values The reported values for analytes are certified or established values for reference materials as reported by institutes such as, but not limited to, the U.S. Geological Survey, the National Institute of Standards and Technology, and the Canadian Certified Reference Materials Project. The reported values are used for the evaluation of accuracy. 


\title{
Chemical Analysis of Archived Stream-Sediment Samples, Alaska
}

\author{
By Bronwen Wang, George N.D. Case, Mathew Granitto, Keith A. Labay, Nora B. Shew, Andrew D. Ingraham, \\ Zachary C. Bueghly, Jaime S. Azain, Susan M. Karl, and Karen D. Kelley
}

\section{Abstract}

Geochemical data are presented for more than 1,500 archived stream-sediment samples and accompanying quality control samples. The archived sediments were reanalyzed to improve the stream geochemical dataset for Alaska and to support ongoing U.S. Geological Survey (USGS) studies. Sediment samples were primarily from the USGS Mineral Resources Program's sample archive in Denver, Colorado, but a few were from the Alaska Geological \& Geophysical Surveys' Geologic Materials Center in Anchorage, Alaska. All samples were submitted to the USGS contract laboratory, AGAT Laboratories, for analysis. All samples were analyzed using a 60-element analytical method involving fusion of the sample by sodium peroxide, dissolution of the fusion cake by nitric acid, and elemental analysis by inductively coupled plasma-optical emission spectroscopy and inductively coupled plasma-mass spectroscopy. Additionally, 106 samples from the Nixon Fork area were analyzed by a second multi-element method involving decomposition by a mixture of hydrochloric, nitric, perchloric, and hydrofluoric acids and the elemental analysis of the resulting solution by inductively coupled plasma-optical emission spectroscopy and inductively coupled plasma-mass spectroscopy. The latter method was used because the detection limit is lower for several elements including As, Cd, Pb, and Sb. Mercury concentrations in 296 samples from southeast Alaska were determined using a coldvapor atomic absorption spectrometry method. The concentration data from the archived samples are presented along with concentration data from the standard reference material that was submitted with the samples.

\section{Introduction}

The U.S. Geological Survey (USGS) Mineral Resources Program maintains an extensive archive of samples that have been analyzed for their chemical composition either by the
USGS or by USGS contract laboratories. The samples are from decades of studies conducted by the USGS Mineral Resources Program and include Alaska samples. In addition to the USGS samples, the archive contains samples collected in the 1970s to early 1980s during the Department of Energy's National Uranium Resource Evaluation (NURE) program. The number of elements determined in the chemical analyses performed on samples collected under these projects were often limited; for example, the rare earth elements were not commonly determined. Some samples were analyzed by the methods that were either only semiquantitative or had detection limits that are high relative to crustal abundance for many elements now of interest, such as tungsten analysis by the NURE program. Reanalysis of the archived pulps is a costeffective means to obtain updated geochemical information. In this report, we present the elemental concentration data for archived samples and standard reference material (SRM) submitted with the samples for three reanalysis efforts performed in 2019 (table 1.1).

\section{Sample Selection}

Samples were selected and analyzed as part of two USGS projects - a mineral prospectivity study and a multidisciplinary study in southeast Alaska, hereinafter called "the transboundary watershed study." Samples for the mineral prospectivity study are broken into two selections, one from the Nixon Fork area and the other from multiple areas that have tungsten-mineralized rock (hereinafter called "the W-focus area") (fig. 1). The Alaska Geochemical Database (AGDB) includes geographic and geochemical information for stream sediment samples in Alaska (Granitto and others, 2011, 2013, 2019). Version 2 (2013) of the database was used in the sample selection process. 


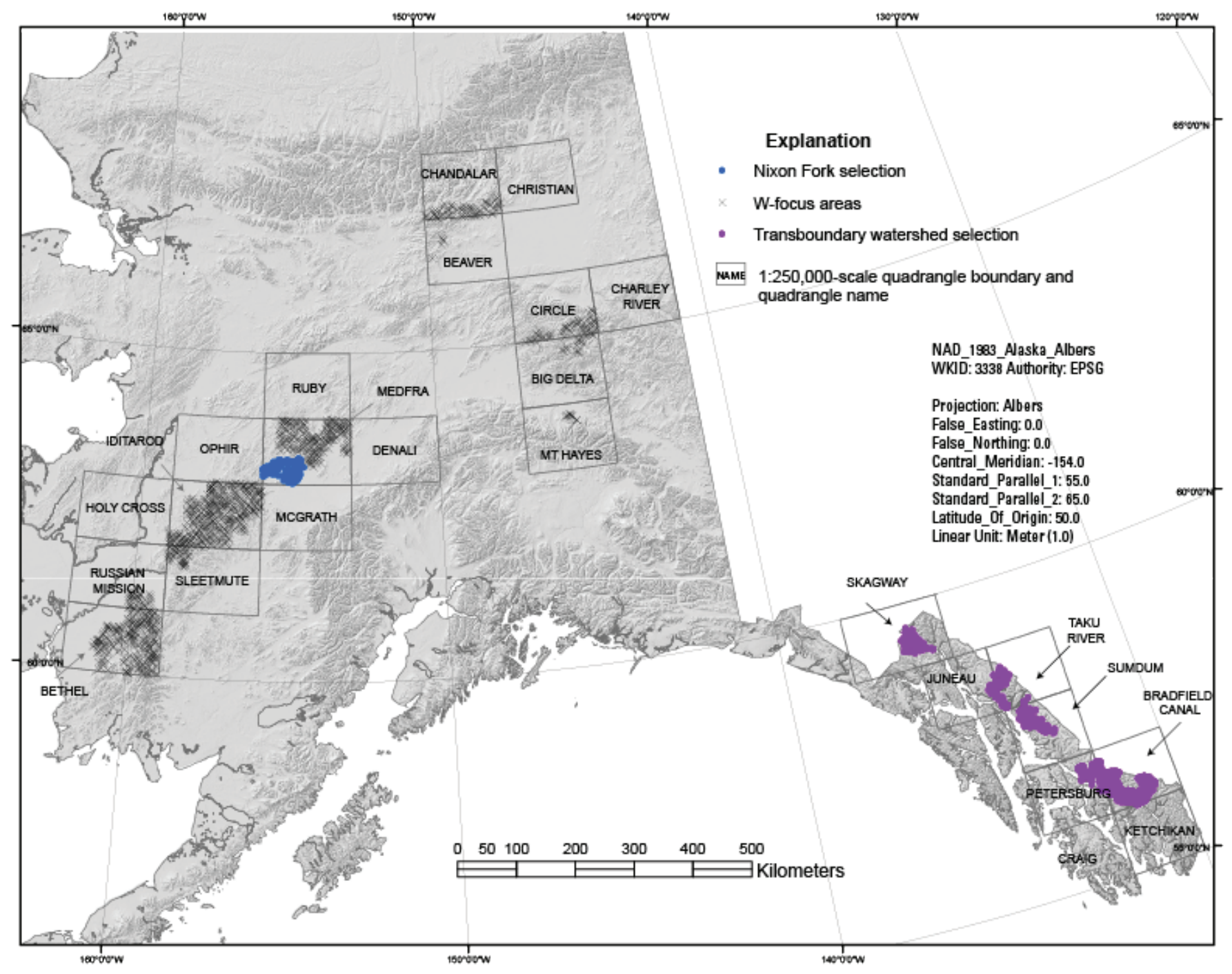

Figure 1. Distribution of samples selected for reanalysis based on U.S. Geological Survey mineral prospectivity and transboundary watershed studies, Alaska.

The samples from the Nixon Fork area were selected to evaluate tungsten concentrations downstream from known mineralized rock and compositional differences between the major subterranes near the Nixon Fork mine. These samples were individually selected based on area geology, location of known mineralized rock, and prior sediment geochemical analysis. Chemical analyses of the samples from the Nixon Fork area were done by two multi-element analysis methods; one uses a sinter method to decompose the sample, and the other uses a multi-acid decomposition method. Both methods have some overlap in the elements analyzed, but by using the two methods, the greatest number of elements could be determined. However, using both methods doubled the weight of sample needed for analyses and increased the cost. For the subsequent selections, only one multi-element method was used, which involved fusion of the entire sample.
Samples for the $\mathrm{W}$-focus area were selected from areas that were considered (based on geologic characteristics) to be prospective for tungsten mineralization but had inadequate stream-sediment geochemical data for assessment studies. In the $\mathrm{W}$-focus areas, a broad spatial distribution was desired. To accommodate these criteria, a target of 3 samples per 12-digit hydrologic unit (HU) was set. The boundaries of the HU were those classified by the Watershed Boundary Dataset (U.S. Geological Survey, 2015; the 12-digit hydrologic units are also known as subwatersheds and have a nationwide areal average of about 40 square miles). Within each $\mathrm{W}$-focus area, samples previously analyzed only by semiquantitative direct-current arc-emission spectrography were selected from the AGDB version 2 as follows. Within each $\mathrm{HU}$, an initial sample was randomly selected. The remaining two samples were selected based on a proximity analysis of the initial point. Each additional sample had to be located the farthest distance possible from the other selections. This ensured that the three samples 
would have a wide spatial distribution within the HU polygon, unlike a completely random selection where samples could cluster.

Samples for the transboundary watershed study were selected to characterize regional background signals and identify tributaries containing mineralized rock that increase the metal concentrations of the Chilkat, Taku, Stikine, and Unuk Rivers in southeast Alaska. The targeted nature of this study required closer spacing and manual selection of samples.

All the samples reanalyzed for the $\mathrm{W}$-focus area, the Nixon Fork area, and transboundary watershed studies were archived sediments that had been previously processed to powders (pulps). Most of the samples were from the USGS archives in Denver, Colorado, but 36 were samples from the Alaska Division of Geological \& Geophysical Surveys' (ADGGS) Geologic Materials Center in Anchorage, Alaska. Most of the samples selected from the USGS archives were collected during USGS studies. However, 49 were collected during the NURE program. Information on the processing characteristics was obtained from the AGDB (Granitto and others, 2013, 2019). Pulp characteristics selected by the three studies are given in table 1.

\section{Sample and Quality Control Sample Submittal}

Samples were submitted to the contract laboratory, AGAT Laboratories, in batches. No more than 50 samples were included in a batch. Reference materials were inserted at random into a batch and made up 10 percent of the batch (for a batch of 50 samples, 45 were samples from the USGS sample archive and 5 were SRMs). The batch is logged into the USGS laboratory information monitoring system (LIMS) with a unique job number and each sample, whether from the archive or a SRM, is assigned a unique sample number (called "the laboratory number" in LIMS and the AGDB version 3) (Granitto and others, 2019). The contract lab receives no other information regarding the samples or the standards other than the unique sample number. Because the standards are sent to the contract laboratory as unknowns and their location within a job is unknown, they can be regarded as double blinds.

The SRMs that were used were blended sediments manufactured by the USGS. They were created to represent sediments sampled from environments associated with varying degrees of mining-operations impacts.

The reference sample abbreviations were slightly inconsistent when they were logged into the LIMS system. The abbreviations used to identify the reference samples in LIMS are those used to identify the SRM samples in table 1.2; they are SAR-L.1 (or SAR-L1), SAR-M.1 (or SAR-M1), SAR-L.2 (or SAR-L2), SAR-M.2 or SRM-(M2), and SAR-H. Briefly, these materials are as follows.

- SAR-L.1 (or SAR-L1) and SAR-M.1 (or SAR-M1): These identifiers found in the reference material column of table 1.2 refer to reference materials that the USGS specially made to insert into contract lab submittals. They represent sediments sampled from environments associated with low and moderately high levels of mining operations impacts, respectively. They were developed for internal USGS use and were not submitted to the International Association of Geoanalysts for certification; consequently, they don't have certified values for their elemental concentrations. However, the USGS has been using these two standards since 2006 and has a robust data compilation for them from which preferred values are calculated. SAR-L1 and SAR-M1 are the predecessors to SAR-L2 and SAR-M2.

- SAR-L.2 or SAR-L2: These identifiers found in the reference material column of table 1.2 refer to the SdAR-L2 reference material available through the International Association of Geoanalysts' website at

Table 1. Collection agency and pulp characteristics.

[Abbreviations and symbols: USGS, U.S. Geological Survey; NURE, National Uranium Resource Evaluation; ADGGS, Alaska Division of Geological \& Geophysical Surveys; <, less then; $\mu \mathrm{m}$, micron; - , not applicable; W-focus area, area prospective for tungsten mineralized rock]

\begin{tabular}{|c|c|c|c|c|}
\hline Area & $\begin{array}{c}\text { Total } \\
\text { sample } \\
\text { number }\end{array}$ & Number of USGS samples; material size & $\begin{array}{c}\text { Number of NURE samples; } \\
\text { material size }\end{array}$ & $\begin{array}{c}\text { Number of ADGGS } \\
\text { samples; material size }\end{array}$ \\
\hline Nixon Fork area & 113 & $64 ;<80$ mesh $(177 \mu \mathrm{m})$ & $49 ;<100$ mesh $(149 \mu \mathrm{m})$ & - \\
\hline $\mathrm{W}$-focus area & 999 & $\begin{array}{l}995 ;<80 \text { mesh }(177 \mu \mathrm{m}) \\
15 ;<80 \text { mesh }(177 \mu \mathrm{m}) \text { and }>230 \\
\text { mesh }(63 \mu \mathrm{m}) \\
2 ;<230 \text { mesh }(63 \mu \mathrm{m}) \\
1 ;<100 \text { mesh }(149 \mu \mathrm{m})\end{array}$ & - & - \\
\hline $\begin{array}{l}\text { Transboundary } \\
\text { watershed }\end{array}$ & 615 & $\begin{array}{l}558 ; \text { size }<80 \text { mesh }(177 \mu \mathrm{m}) \\
1 ;<20 \text { mesh }(841 \mu \mathrm{m}) \text { and }>80 \text { mesh } \\
(177 \mu \mathrm{m}) \\
21 ;>5 \operatorname{mesh}(4,000 \mu \mathrm{m})\end{array}$ & - & 36; unknown \\
\hline
\end{tabular}


http://www.geoanalyst.org (International Association of Geoanalysts, 2020). SdAR-L2 is a blend of sediments and is designed to resemble sediments sampled when monitoring low levels of environmental contamination associated with discharges from mining operations. It was tested by the International Association of Geoanalysts, has certificated values, and is appropriate for use in quality control programs (Webb and others, 2015a; International Association of Geoanalysts, 2019a).

- SAR-M.2 or SAR-M2: These identifiers found in the reference material column of table 1.2 refer to the SdAR-M2 reference material available through the International Association of Geoanalysts' website at http://www.geoanalyst.org (International Association of Geoanalysts, 2020). SdAR-M2 is a blend of sediments designed to resemble sediments sampled when monitoring moderately high levels of environmental contamination associated with discharges from mining operations. This SRM was tested by the International Association of Geoanalysts, has certified values, and is appropriate for use in quality control programs (Webb and others, 2015b; International Association of Geoanalysts, 2019b).
- SAR-H: This identifier found in the reference material column of table 1.2 refers to the SdAR-H1 reference material available through the International Association of Geoanalysts' website at http://www.geoanalyst.org_ (International Association of Geoanalysts, 2020). SdAR-H1 is a blend of sediments designed to resemble sediments sampled when monitoring high levels of environmental contamination associated with discharges from mining operations. This SRM was tested by the International Association of Geoanalysts, has certified values, and is appropriate for use in quality control programs. (Webb and others, 2014; International Association of Geoanalysts, 2019c).

The preferred and certified values for the SRMs are given in table 2.

For most of the archived samples, only a single aliquot of the sample was analyzed. Four samples from the Nixon Fork area had enough sample mass for a separate aliquot to be sent as a blind duplicate sample. Additionally, one standard (SAR-L2) was sent as a blind duplicate along with samples from the Nixon Fork area as reported in table 1.2. 
Table 2. Preferred values for the standard reference materials SAR-L.1 and SAR-M.1 and certified values for SAR-H, SAR-L2, and SAR-M.2.

[Element: For the name associated with each entry, see the "Chemical Symbols" list in the front matter of this report. Abbreviations: $\mathrm{mg} / \mathrm{kg}$, milligrams per kilogram; wt. \%, weight percent]

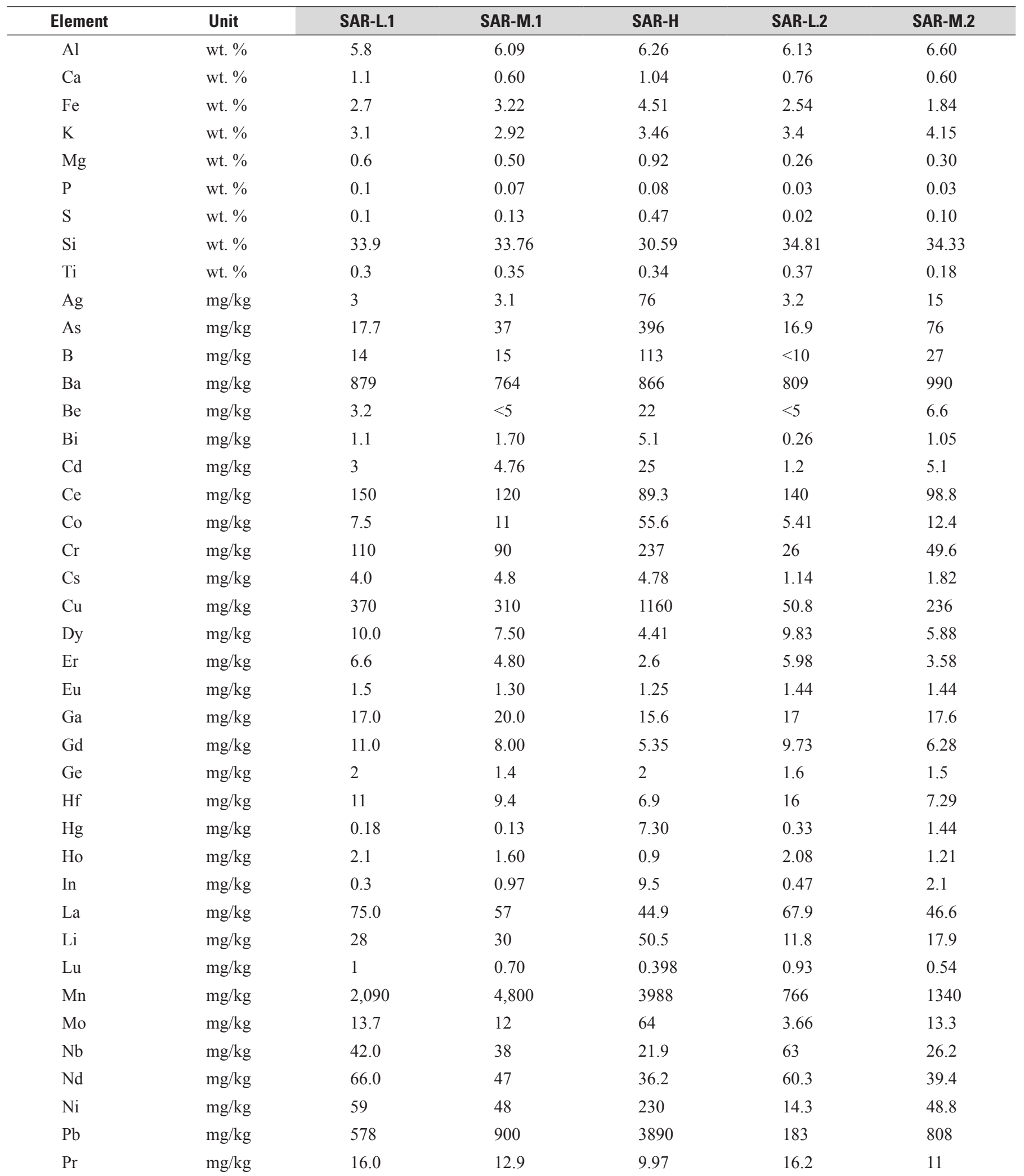


Table 2. Preferred values for the standard reference materials SAR-L.1 and SAR-M.1 and certified values for SAR-H, SAR-L2, and SAR-M.2.-Continued

[Element: For the name associated with each entry, see the "Chemical Symbols" list in the front matter of this report. Abbreviations: mg/kg, milligrams per kilogram; wt. \%, weight percent]

\begin{tabular}{ccccccc}
\hline Element & Unit & SAR-L.1 & SAR-M.1 & SAR-H & SAR-L.2 & SAR-M.2 \\
\hline $\mathrm{Rb}$ & $\mathrm{mg} / \mathrm{kg}$ & 140 & 142 & 152 & 120 & 149.2 \\
$\mathrm{Sb}$ & $\mathrm{mg} / \mathrm{kg}$ & 5.1 & 6.3 & 505 & 21.8 & 107 \\
$\mathrm{Sc}$ & $\mathrm{mg} / \mathrm{kg}$ & 7 & 8 & 8.2 & 5.6 & $<5$ \\
$\mathrm{Se}$ & $\mathrm{mg} / \mathrm{kg}$ & 0.9 & $<5$ & 15 & $<5$ & 2.70 \\
$\mathrm{Sm}$ & $\mathrm{mg} / \mathrm{kg}$ & 11.4 & 9 & 6.39 & 11.5 & 7.18 \\
$\mathrm{Sn}$ & $\mathrm{mg} / \mathrm{kg}$ & 5 & 3.5 & 2.9 & 3.2 & 2.40 \\
$\mathrm{Sr}$ & $\mathrm{mg} / \mathrm{kg}$ & 158 & 156 & 182 & 150 & 144 \\
$\mathrm{Ta}$ & $\mathrm{mg} / \mathrm{kg}$ & 2.1 & 2 & 1.41 & 3.81 & 1.80 \\
$\mathrm{~Tb}$ & $\mathrm{mg} / \mathrm{kg}$ & 1.7 & 1.3 & 0.78 & 1.58 & 0.97 \\
$\mathrm{Te}$ & $\mathrm{mg} / \mathrm{kg}$ & 0.5 & 1 & 9.5 & $<0.5$ & 2.1 \\
$\mathrm{Th}$ & $\mathrm{mg} / \mathrm{kg}$ & 19 & 18 & 17.7 & 22 & 14.2 \\
$\mathrm{Tl}$ & $\mathrm{mg} / \mathrm{kg}$ & 1.2 & 2.8 & 11.1 & 0.99 & 2.8 \\
$\mathrm{Tm}$ & $\mathrm{mg} / \mathrm{kg}$ & 0.9 & 0.68 & 0.394 & 0.92 & 0.54 \\
$\mathrm{U}$ & $\mathrm{mg} / \mathrm{kg}$ & 4.6 & 4.7 & 4.07 & 3.34 & 2.53 \\
$\mathrm{~V}$ & $\mathrm{mg} / \mathrm{kg}$ & 131 & 66 & 73.2 & 35 & 25.2 \\
$\mathrm{~W}$ & $\mathrm{mg} / \mathrm{kg}$ & 3.7 & 11 & 13 & 1.72 & 3.5 \\
$\mathrm{Y}$ & $\mathrm{mg} / \mathrm{kg}$ & 57 & 42 & 25.4 & 54.6 & 32.7 \\
$\mathrm{Yb}$ & $\mathrm{mg} / \mathrm{kg}$ & 6.3 & 4.9 & 2.6 & 6.1 & 3.63 \\
$\mathrm{Zn}$ & $\mathrm{mg} / \mathrm{kg}$ & 420 & 890 & 3680 & 201 & 760 \\
$\mathrm{Zr}$ & $\mathrm{mg} / \mathrm{kg}$ & 400 & 361 & 258 & 618 & 259 \\
\hline
\end{tabular}

\section{Analytical Methods Used}

All sample analyses were performed by AGAT Laboratories under contract with the USGS. The method information summarized below was provided by AGAT Laboratories.

The samples for all three study areas used a multielement analytical method in which a 0.5 gram $(\mathrm{g})$ sample is fused at $750{ }^{\circ} \mathrm{C}$ with sodium peroxide and the fusion cake is dissolved in dilute nitric acid. The elemental composition of the resulting solution is determined by inductively coupled plasma-optical emission spectroscopy (ICP-OES) and inductively coupled plasma-mass spectroscopy (ICP-MS). The reporting limits and detector used are listed by element in table 3. In this report, this method is referred to as "the fusion method." The method is similar to sinter methods used by the USGS and previous contract laboratories.

Most samples from the Nixon Fork area were also analyzed by a second multi-element method in which a $0.5 \mathrm{~g}$ sample is decomposed using a mixture of hydrochloric, nitric, perchloric, and hydrofluoric acids at low temperature and the elemental composition of the resulting solution is determined by ICP-OES and ICP-MS. The reporting limits and detector used are listed by element in table 4 . In this report, this method is referred to as the four-acid method. The method is similar to four-acid methods used by the USGS and previous contract laboratories.

Selected samples of the transboundary watershed study were also analyzed for mercury by using a cold vapor atomic absorption spectrometry (CVAAS) method. In this method, a $0.5 \mathrm{~g}$ sample is digested using a mixture of sulfuric and nitric acids, dilute potassium permanganate, and dilute potassium persulfate in a water bath. Excess potassium permanganate is reduced by hydroxylamine sulfate solution, then $\mathrm{Hg}$ (II) is reduced by a solution of $\mathrm{Sn}$ (II) chloride (or stannous chloride). Mercury vapor is separated and measured with a flow injection mercury system (FIMS 100 Mercury Analysis System). The reporting limit range for mercury by this method is $1-1,000$ parts per billion. 
Table 3. The upper and lower reporting limit and analytical instrument used for elemental determination by element for the fusion method of AGAT Laboratories.

[Element: For the name associated with each entry, see the "Chemical Symbols" list in the front matter of this report. Abbreviations: mg/kg, milligrams per kilogram; wt. \%, weight percent; ICP-MS, inductively coupled plasma-mass spectroscopy; ICP-OES, inductively coupled plasma-optical emission spectroscopy]

\begin{tabular}{|c|c|c|c|}
\hline Element & Lower reporting limit & Upper reporting limit & Instrument \\
\hline $\mathrm{Ag}$ & $1 \mathrm{mg} / \mathrm{kg}$ & $1,000 \mathrm{mg} / \mathrm{kg}$ & ICP-MS \\
\hline $\mathrm{Al}$ & 0.01 wt. $\%$ & 25 wt. $\%$ & ICP-OES \\
\hline As & $5 \mathrm{mg} / \mathrm{kg}$ & 10 wt. $\%$ & ICP-MS \\
\hline B & $10 \mathrm{mg} / \mathrm{kg}$ & 1 wt. $\%$ & ICP-MS \\
\hline $\mathrm{Ba}$ & $0.5 \mathrm{mg} / \mathrm{kg}$ & 1 wt. $\%$ & ICP-OES \\
\hline $\mathrm{Be}$ & $5 \mathrm{mg} / \mathrm{kg}$ & 0.25 wt. $\%$ & ICP-OES \\
\hline $\mathrm{Bi}$ & $0.1 \mathrm{mg} / \mathrm{kg}$ & 0.1 wt. $\%$ & ICP-MS \\
\hline $\mathrm{Ca}$ & 0.01 wt. $\%$ & 35 wt. $\%$ & ICP-OES \\
\hline $\mathrm{Cd}$ & $0.2 \mathrm{mg} / \mathrm{kg}$ & 1 wt. $\%$ & ICP-MS \\
\hline $\mathrm{Ce}$ & $0.1 \mathrm{mg} / \mathrm{kg}$ & 1 wt. $\%$ & ICP-MS \\
\hline $\mathrm{Co}$ & $0.5 \mathrm{mg} / \mathrm{kg}$ & 1 wt. $\%$ & ICP-MS \\
\hline $\mathrm{Cr}$ & $10 \mathrm{mg} / \mathrm{kg}$ & 10 wt. $\%$ & ICP-OES \\
\hline Cs & $0.1 \mathrm{mg} / \mathrm{kg}$ & 1wt. $\%$ & ICP-MS \\
\hline $\mathrm{Cu}$ & $5 \mathrm{mg} / \mathrm{kg}$ & 5 wt. $\%$ & ICP-OES \\
\hline Dy & $0.05 \mathrm{mg} / \mathrm{kg}$ & 0.1 wt. $\%$ & ICP-MS \\
\hline $\mathrm{Er}$ & $0.05 \mathrm{mg} / \mathrm{kg}$ & 0.1 wt. $\%$ & ICP-MS \\
\hline $\mathrm{Eu}$ & $0.05 \mathrm{mg} / \mathrm{kg}$ & 0.1 wt. $\%$ & ICP-MS \\
\hline $\mathrm{Fe}$ & 0.01 wt. $\%$ & 30 wt. $\%$ & ICP-OES \\
\hline $\mathrm{Ga}$ & $0.01 \mathrm{mg} / \mathrm{kg}$ & 0.1 wt. $\%$ & ICP-MS \\
\hline Gd & $0.05 \mathrm{mg} / \mathrm{kg}$ & 0.1 wt. $\%$ & ICP-MS \\
\hline $\mathrm{Ge}$ & $1 \mathrm{mg} / \mathrm{kg}$ & 0.1 wt. $\%$ & ICP-MS \\
\hline Hf & $1 \mathrm{mg} / \mathrm{kg}$ & 1 wt. $\%$ & ICP-MS \\
\hline Ho & $0.05 \mathrm{mg} / \mathrm{kg}$ & 0.1 wt. $\%$ & ICP-MS \\
\hline In & $0.2 \mathrm{mg} / \mathrm{kg}$ & 0.1 wt. $\%$ & ICP-MS \\
\hline $\mathrm{K}$ & 0.01 wt. $\%$ & 25 wt. $\%$ & ICP-OES \\
\hline $\mathrm{La}$ & $0.1 \mathrm{mg} / \mathrm{kg}$ & 1 wt. $\%$ & ICP-MS \\
\hline $\mathrm{Li}$ & $10 \mathrm{mg} / \mathrm{kg}$ & 5 wt. $\%$ & ICP-OES \\
\hline $\mathrm{Lu}$ & $0.05 \mathrm{mg} / \mathrm{kg}$ & 0.1 wt. $\%$ & ICP-MS \\
\hline $\mathrm{Mg}$ & 0.01 wt. $\%$ & 30 wt. $\%$ & ICP-OES \\
\hline $\mathrm{Mn}$ & $10 \mathrm{mg} / \mathrm{kg}$ & 10 wt. $\%$ & ICP-OES \\
\hline Mo & $2 \mathrm{mg} / \mathrm{kg}$ & 1 wt. $\%$ & ICP-MS \\
\hline $\mathrm{Nb}$ & $0.1 \mathrm{mg} / \mathrm{kg}$ & 1 wt. $\%$ & ICP-MS \\
\hline $\mathrm{Nd}$ & $0.1 \mathrm{mg} / \mathrm{kg}$ & 1 wt. $\%$ & ICP-MS \\
\hline $\mathrm{Ni}$ & $5 \mathrm{mg} / \mathrm{kg}$ & 1 wt. $\%$ & ICP-OES \\
\hline $\mathrm{P}$ & 0.01 wt. $\%$ & 25 wt. $\%$ & ICP-OES \\
\hline $\mathrm{Pb}$ & $5 \mathrm{mg} / \mathrm{kg}$ & 5 wt. $\%$ & ICP-MS \\
\hline $\operatorname{Pr}$ & $0.05 \mathrm{mg} / \mathrm{kg}$ & 5 wt. $\%$ & ICP-MS \\
\hline $\mathrm{Rb}$ & $0.2 \mathrm{mg} / \mathrm{kg}$ & 1 wt. $\%$ & ICP-MS \\
\hline $\mathrm{S}$ & 0.1 wt. $\%$ & 40 wt. $\%$ & ICP-OES \\
\hline $\mathrm{Sb}$ & $0.1 \mathrm{mg} / \mathrm{kg}$ & 1 wt. $\%$ & ICP-MS \\
\hline $\mathrm{Sc}$ & $5 \mathrm{mg} / \mathrm{kg}$ & 5 wt. $\%$ & ICP-OES \\
\hline
\end{tabular}


Table 3. The upper and lower reporting limit and analytical instrument used for elemental determination by element for the fusion method of AGAT Laboratories.-Continued

[Element: For the name associated with each entry, see the "Chemical Symbols" list in the front matter of this report. Abbreviations: $\mathrm{mg} / \mathrm{kg}$, milligrams per kilogram; wt. \%, weight percent; ICP-MS, inductively coupled plasma-mass spectroscopy; ICP-OES, inductively coupled plasma-optical emission spectroscopy]

\begin{tabular}{|c|c|c|c|}
\hline Element & Lower reporting limit & Upper reporting limit & Instrument \\
\hline $\mathrm{Se}$ & $5 \mathrm{mg} / \mathrm{kg}$ & 0.1 wt. $\%$ & ICP-MS \\
\hline $\mathrm{Si}$ & 0.01 wt. $\%$ & 40 wt. $\%$ & ICP-OES \\
\hline $\mathrm{Sm}$ & $0.1 \mathrm{mg} / \mathrm{kg}$ & 0.1 wt. $\%$ & ICP-MS \\
\hline Sn & $1 \mathrm{mg} / \mathrm{kg}$ & 1 wt. $\%$ & ICP-MS \\
\hline $\mathrm{Sr}$ & $0.1 \mathrm{mg} / \mathrm{kg}$ & 1 wt. $\%$ & ICP-OES \\
\hline $\mathrm{Ta}$ & $0.5 \mathrm{mg} / \mathrm{kg}$ & 1 wt. $\%$ & ICP-MS \\
\hline $\mathrm{Tb}$ & $0.05 \mathrm{mg} / \mathrm{kg}$ & 0.1 wt. $\%$ & ICP-MS \\
\hline $\mathrm{Te}$ & $0.5 \mathrm{mg} / \mathrm{kg}$ & 0.1 wt. $\%$ & ICP-MS \\
\hline Th & $0.1 \mathrm{mg} / \mathrm{kg}$ & 0.1 wt. $\%$ & ICP-MS \\
\hline $\mathrm{Ti}$ & 0.01 wt. $\%$ & 25 wt. $\%$ & ICP-OES \\
\hline $\mathrm{Tl}$ & $0.5 \mathrm{mg} / \mathrm{kg}$ & 0.1 wt. $\%$ & ICP-MS \\
\hline $\mathrm{Tm}$ & $0.05 \mathrm{mg} / \mathrm{kg}$ & 0.1 wt. $\%$ & ICP-MS \\
\hline $\mathrm{U}$ & $0.05 \mathrm{mg} / \mathrm{kg}$ & 0.1 wt. $\%$ & ICP-MS \\
\hline $\mathrm{V}$ & $5 \mathrm{mg} / \mathrm{kg}$ & 1 wt. $\%$ & ICP-OES \\
\hline $\mathrm{W}$ & $1 \mathrm{mg} / \mathrm{kg}$ & 1 wt. $\%$ & ICP-MS \\
\hline $\mathrm{Y}$ & $0.5 \mathrm{mg} / \mathrm{kg}$ & 1 wt. $\%$ & ICP-MS \\
\hline $\mathrm{Yb}$ & $0.1 \mathrm{mg} / \mathrm{kg}$ & 0.1 wt. $\%$ & ICP-MS \\
\hline $\mathrm{Zn}$ & $5 \mathrm{mg} / \mathrm{kg}$ & 5 wt. $\%$ & ICP-OES \\
\hline $\mathrm{Zr}$ & $0.5 \mathrm{mg} / \mathrm{kg}$ & 1 wt. $\%$ & ICP-MS \\
\hline
\end{tabular}

Total sulfur in job numbers MRP-17993, MRP-17994, MRP-18027, and MRP-18028 (see appendix table 1.1 column "Job_No") of W-focus area was determined by a combustion method due to the high carbon content of the samples. In this method, a $1 \mathrm{~g}$ sample is mixed with an accelerator and heated via an induction furnace to oxidize sulfur to sulfur dioxide. Moisture and dust are removed, and the sulfur dioxide gas is then measured by a solid-state infrared detector. The reporting limit range for total sulfur is $0.005-100$ percent.

\section{Analytical Performance}

The USGS contract requires that the contract laboratory insert blanks, their own SRMs (these SRMs are in addition to the double-blind SRMs inserted into the sample batch by the USGS), and sample duplicates. Prior to releasing the data to the USGS, the laboratory evaluates the data for acceptability. The criteria for acceptance for the methods used on the samples included in this report are as follows:

1. Data determined by the fusion method are considered acceptable if recovery of each element is \pm 15 percent at five times the lower limit of determination (LOD) and the relative standard deviation (RSD) of duplicate samples is no greater than 15 percent.
2. Data determined by the four-acid method are considered acceptable if recovery of each element is \pm 15 percent at five times the LOD and the RSD of duplicate samples is no greater than 15 percent.

3. Mercury data are acceptable if recovery is \pm 20 percent at five times the LOD and the calculated RSD of duplicate samples is no greater than 20 percent.

4. Total Sulfur data are acceptable if recovery is \pm 15 percent at five times the LOD and the RSD of duplicate samples is no greater than 15 percent.

When the acceptance criteria are not met, reanalysis is required. Additionally, if any elements are above the upper reporting limit, then that sample is diluted to bring the solution within the concentration of the method. The sample is reanalyzed, the appropriate dilution factor is applied, and the concentration is reported as an unqualified (meaning without a greater than designation) value. Consequently, some elements may be reported at values that exceed the upper reporting limit for the analysis given above. 
Table 4. Upper and lower reporting limit and analytical instrument used for elemental determination by element for the four-acid method of AGAT Laboratories.

[Element: For the name associated with each entry, see the "Chemical Symbols" list in the front matter of this report. Abbreviations: $\mathrm{mg} / \mathrm{kg}$, milligrams per kilogram; wt. \%, weight percent; ICP-MS, inductively coupled plasma-mass spectroscopy; ICP-OES, inductively coupled plasma-optical emission spectroscopy]

\begin{tabular}{|c|c|c|c|}
\hline Element & Lower reporting Limit & Upper reporting limit & Instrument \\
\hline $\mathrm{Ag}$ & $0.01 \mathrm{mg} / \mathrm{kg}$ & $100 \mathrm{mg} / \mathrm{kg}$ & ICP-MS \\
\hline $\mathrm{Al}$ & 0.01 wt. $\%$ & 15 wt. $\%$ & ICP-OES \\
\hline As & $0.2 \mathrm{mg} / \mathrm{kg}$ & 1 wt. $\%$ & ICP-MS \\
\hline $\mathrm{Ba}$ & $1 \mathrm{mg} / \mathrm{kg}$ & 1wt. \% & ICP-OES \\
\hline $\mathrm{Be}$ & $0.05 \mathrm{mg} / \mathrm{kg}$ & $2,500 \mathrm{mg} / \mathrm{kg}$ & ICP-MS \\
\hline $\mathrm{Bi}$ & $0.01 \mathrm{mg} / \mathrm{kg}$ & 1 wt. $\%$ & ICP-MS \\
\hline $\mathrm{Ca}$ & 0.01 wt. $\%$ & 15 wt. $\%$ & ICP-OES \\
\hline $\mathrm{Cd}$ & $0.02 \mathrm{mg} / \mathrm{kg}$ & 1wt. $\%$ & ICP-MS \\
\hline $\mathrm{Ce}$ & $0.01 \mathrm{mg} / \mathrm{kg}$ & $1,000 \mathrm{mg} / \mathrm{kg}$ & ICP-MS \\
\hline Co & $0.05 \mathrm{mg} / \mathrm{kg}$ & 1 wt. $\%$ & ICP-MS \\
\hline $\mathrm{Cr}$ & $0.5 \mathrm{mg} / \mathrm{kg}$ & 1 wt. $\%$ & ICP-OES \\
\hline $\mathrm{Cs}$ & $0.01 \mathrm{mg} / \mathrm{kg}$ & $1,000 \mathrm{mg} / \mathrm{kg}$ & ICP-MS \\
\hline $\mathrm{Cu}$ & $0.5 \mathrm{mg} / \mathrm{kg}$ & 1 wt. $\%$ & ICP-OES \\
\hline $\mathrm{Fe}$ & 0.01 wt. $\%$ & 15 wt. $\%$ & ICP-OES \\
\hline $\mathrm{Ga}$ & $0.05 \mathrm{mg} / \mathrm{kg}$ & $500 \mathrm{mg} / \mathrm{kg}$ & ICP-MS \\
\hline Hf & $0.1 \mathrm{mg} / \mathrm{kg}$ & $500 \mathrm{mg} / \mathrm{kg}$ & ICP-MS \\
\hline In & $0.005 \mathrm{mg} / \mathrm{kg}$ & $500 \mathrm{mg} / \mathrm{kg}$ & ICP-MS \\
\hline $\mathrm{K}$ & 0.01 wt. $\%$ & 15 wt. $\%$ & ICP-OES \\
\hline $\mathrm{La}$ & $0.5 \mathrm{mg} / \mathrm{kg}$ & 1 wt. $\%$ & ICP-MS \\
\hline $\mathrm{Li}$ & $0.1 \mathrm{mg} / \mathrm{kg}$ & 1 wt. $\%$ & ICP-OES \\
\hline $\mathrm{Lu}$ & $0.01 \mathrm{mg} / \mathrm{kg}$ & $1,000 \mathrm{mg} / \mathrm{kg}$ & ICP-MS \\
\hline $\mathrm{Mg}$ & 0.01 wt. $\%$ & 15 wt. $\%$ & ICP-OES \\
\hline $\mathrm{Mn}$ & $1 \mathrm{mg} / \mathrm{kg}$ & 1 wt. $\%$ & ICP-OES \\
\hline Mo & $0.05 \mathrm{mg} / \mathrm{kg}$ & 1 wt. $\%$ & ICP-MS \\
\hline $\mathrm{Na}$ & 0.01 wt. $\%$ & 15 wt. $\%$ & ICP-OES \\
\hline $\mathrm{Nb}$ & $0.1 \mathrm{mg} / \mathrm{kg}$ & 0.1 wt. $\%$ & ICP-MS \\
\hline $\mathrm{Ni}$ & $0.5 \mathrm{mg} / \mathrm{kg}$ & 1 wt. $\%$ & ICP-OES \\
\hline $\mathrm{P}$ & $10 \mathrm{mg} / \mathrm{kg}$ & 15 wt. $\%$ & ICP-OES \\
\hline $\mathrm{Pb}$ & $0.1 \mathrm{mg} / \mathrm{kg}$ & 1 wt. $\%$ & ICP-MS \\
\hline $\mathrm{Rb}$ & $0.1 \mathrm{mg} / \mathrm{kg}$ & 1 wt. $\%$ & ICP-MS \\
\hline $\mathrm{S}$ & 0.01 wt. $\%$ & 5 wt. $\%$ & ICP-OES \\
\hline $\mathrm{Sb}$ & $0.05 \mathrm{mg} / \mathrm{kg}$ & 1 wt. $\%$ & ICP-MS \\
\hline $\mathrm{Sc}$ & $0.1 \mathrm{mg} / \mathrm{kg}$ & 1 wt. $\%$ & ICP-MS \\
\hline $\mathrm{Se}$ & $0.5 \mathrm{mg} / \mathrm{kg}$ & 0.1 wt. $\%$ & ICP-MS \\
\hline $\mathrm{Sn}$ & $0.2 \mathrm{mg} / \mathrm{kg}$ & 0.1 wt. $\%$ & ICP-MS \\
\hline $\mathrm{Sr}$ & $0.2 \mathrm{mg} / \mathrm{kg}$ & 1 wt. $\%$ & ICP-OES \\
\hline $\mathrm{Ta}$ & $0.05 \mathrm{mg} / \mathrm{kg}$ & 1 wt. $\%$ & ICP-MS \\
\hline $\mathrm{Tb}$ & $0.05 \mathrm{mg} / \mathrm{kg}$ & 1 wt. $\%$ & ICP-MS \\
\hline $\mathrm{Te}$ & $0.01 \mathrm{mg} / \mathrm{kg}$ & 0.1 wt. $\%$ & ICP-MS \\
\hline Th & $0.1 \mathrm{mg} / \mathrm{kg}$ & 1 wt. $\%$ & ICP-MS \\
\hline $\mathrm{Ti}$ & 0.01 wt. $\%$ & 15 wt. $\%$ & ICP-OES \\
\hline
\end{tabular}


Table 4. Upper and lower reporting limit and analytical instrument used for elemental determination by element for the four-acid method of AGAT Laboratories.-Continued

[Element: For the name associated with each entry, see the "Chemical Symbols" list in the front matter of this report. Abbreviations: $\mathrm{mg} / \mathrm{kg}$, milligrams per kilogram; wt. \%, weight percent; ICP-MS, inductively coupled plasma-mass spectroscopy; ICP-OES, inductively coupled plasma-optical emission spectroscopy]

\begin{tabular}{cccl}
\hline Element & Lower reporting Limit & Upper reporting limit & Instrument \\
\hline $\mathrm{Tl}$ & $0.01 \mathrm{mg} / \mathrm{kg}$ & $1 \mathrm{wt.} \%$ & ICP-MS \\
$\mathrm{U}$ & $0.005 \mathrm{mg} / \mathrm{kg}$ & $1 \mathrm{wt} \%$ & ICP-MS \\
$\mathrm{V}$ & $0.5 \mathrm{mg} / \mathrm{kg}$ & $1 \mathrm{wt} \%$ & ICP-OES \\
$\mathrm{W}$ & $0.1 \mathrm{mg} / \mathrm{kg}$ & $1 \mathrm{wt} \%$ & ICP-MS \\
$\mathrm{Y}$ & $0.1 \mathrm{mg} / \mathrm{kg}$ & $1 \mathrm{wt.} \%$ & ICP-MS \\
$\mathrm{Yb}$ & $0.1 \mathrm{mg} / \mathrm{kg}$ & $0.1 \mathrm{wt} \%$ & ICP-MS \\
$\mathrm{Zn}$ & $0.5 \mathrm{mg} / \mathrm{kg}$ & 1 wt. $\%$ & ICP-OES \\
$\mathrm{Zr}$ & $0.5 \mathrm{mg} / \mathrm{kg}$ & 1 wt. $\%$ & ICP-MS \\
\hline
\end{tabular}

\section{Data Evaluation}

When the USGS receives data for a batch of samples from a contract laboratory, the elemental concentrations determined for the reference samples inserted by the USGS into the sample batch are compared to (1) the preferred values for, or the certified value of, an element, (2) the long-term (from 2006 to 2017) mean value for the SRMs determined on the reference materials by the same or analogous methods of previous contract laboratories, and (3) the spread of concentrations for the reference material seen in the long-term data. Values above 15 percent of both the preferred or censored value and the long-term mean are checked against certificate values for tolerance ranges when available. Any values that cannot be verified are flagged for further evaluation. For flagged elements, the internal laboratory replicates and reference materials are reviewed, and the performance of the method on the other reference materials included in the batch is considered. If most of the other reference materials in the batch are also above 15 percent, reanalysis is required. If the elements in question have known limitations for the method of analysis, the element is marked as informational.

All batches for the Nixon Fork area, the W-focus area, and the transboundary watershed studies were reviewed. No data were marked as informational. One sample has a reported iron $(\mathrm{Fe}$ ) content of $35.7 \mathrm{wt}$. percent (sample is C-489089 in job MPR-18138), which appears to exceed the upper reporting limit of $30 \mathrm{wt}$. percent for iron by the sinter method. The reported silicon $(\mathrm{Si})$ contents in two samples appear to exceed the methods upper reporting limit of $40 \mathrm{wt}$. percent (44.9 wt. percent for C-485804 in job MPR-18029 and 40.3 wt. percent for sample C-484123 in job MPR-17986). The samples were diluted to bring the solutions within the operating range of the method and reanalyzed to achieve a quantitative result for the samples (see the "Analytical Performance" section for details).

\section{Data}

The analyses for the archived samples selected in the Nixon Fork area, the tungsten-mineralization focus area, and the transboundary watershed studies are provided in the table 1.1. Sample latitude and longitude (Latitude_AGDB3, Longitude AGDB3) for the samples and the pulp size (MESH_PORE_SIZE_AGDB3) were obtained from AGDB version 3.0 and included in table 1.1. The analyses of the reference materials are given in table 1.2. For those interested in relating the SRMs to the archived samples with which they were run, the unique job number assigned to a sample batch is given in the "Job No" column of the data and SRM tables. For those wishing to relate the sample analysis to additional sample information or any prior analysis in the AGDB version 3.0 (Granitto and others, 2019), the unique sample identifier "AGBD_ID," 'is included in column "AGBD_ID_AGDB3" in table 1.1.

The appendix contains two tables in Microsoft Excel format. All values below detection are presented as negative numbers at the reporting limit of the element; for example, if the reporting limit for silver is 1 part per million (ppm) and the concentration in the sample is below detection, the silver concentration will be given as $-1 \mathrm{ppm}$.

Table 1.1 presents elemental concentration data for the stream sediments analyzed in support of mineral prospectivity studies done by the USGS in Alaska (in the area of Nixon Fork and multiple sites that have tungsten-mineralized rock) and a multidisciplinary study done in southeast Alaska, hereinafter called the "transboundary watershed study." Table 1.2 presents elemental-concentration data for the standard reference materials and the duplicate stream sediment samples that were run as part of the Nixon Fork area.

The tables in the appendixes are also released in machinereadable format containing only one row of header information in a companion data release (Wang and others, 2021). In all ways other than in name, table 1.1 is identical to the 
geology_geochemData_Alaska_wang_2019.csv data release table, and table 1.2 is identical to the geology_geochemQC Alaska_wang_2019.csv data release table. The concentration data are presented in columns, with one column for each element determined by a specific method. Concentrations below the method's lower-reporting limit are represented as negative numbers, and the lower-reporting limit is the absolute value of reported value. Column headers are structured as follows:

Chemical symbol of the element units of determination analytical instrument code_digestion method code.

A list of the chemical symbols is given at the front of this report. For ease of machine reading, the concentration units are given using the abbreviations "pct" for weight percent and "ppm" for parts per millions (equivalent to $\mathrm{mg} / \mathrm{kg}$ ). Method codes are similar to those used in AGBD3. However, the acronym OES indicates analysis by inductively coupled plasmaoptical emission spectroscopy rather than AES which is the acronym for the more general term atomic emission spectroscopy. Method codes are as follows:

- ICP_OES_ST: inductively coupled plasma-optical emission spectroscopy following a fusion method decomposition

- ICP_OES_HF: inductively coupled plasma-optical emission spectroscopy following a decomposition using a mixture of hydrochloric, nitric, perchloric, and hydrofluoric acids at low temperature

- ICP_MS_ST: inductively coupled plasma-mass spectroscopy following a fusion method decomposition

- ICP_MS_HF: inductively coupled plasma-mass spectroscopy following a decomposition using a mixture of hydrochloric, nitric, perchloric, and hydrofluoric acids at low temperature

- CVAA: cold vapor atomic absorption spectrometry method

Selected information from AGDB version 3.0 (Granitto and others, 2019) is included on the data tables 1.1 and 1.2 Information included is the unique sample identifier, AGBD_ID, sample latitude and longitude, (Latitude_AGDB3, Longitude_AGDB3), and the pulp size (MESH_PORE_SIZE_ AGDB3). For those wishing to relate the sample analysis to additional sample information or any prior analysis for the sample available in the Alaska Geochemical Database version 3.0 (Granitto and others, 2019), the unique sample identifier, AGBD_ID can be used to relate the samples to all additional information in the Alaska Geochemical Database version 3.0 (Granitto and others, 2019).

\section{References Cited}

Granitto, M., Bailey, E.A., Schmidt, J.M., Shew, N.B., Gamble, B.M., and Labay, K.A., 2011, Alaska Geochemical Database (AGDB) - Geochemical data for rock, sediment, soil, mineral, and concentrate sample media: U.S. Geological Survey Data Series 637, 39 p. + pamphlet + database + 1 DVD, accessed January 24, 2020, at https://doi.org/10.3133/ds637.

Granitto, M., Schmidt, J.M., Shew, N.B., Gamble, B.M., and Labay, K.A., 2013, Alaska Geochemical Database version 2.0 (AGDB2) - Including "best value" data compilations for geochemical data for rock, sediment, soil, mineral, and concentrate sample media: U.S. Geological Survey Data Series 759, 20 p. + 1 DVD, accessed January 24, 2020, at ht tps://pubs.usgs.gov/ds/759/

Granitto, M., Wang, B., Shew, N.B., Karl, S.M., Labay, K.A., Werdon, M.B., Seitz, S.S., and Hoppe, J.E., 2019, Alaska Geochemical Database version 3.0 (AGDB3)_-Including "best value" data compilation for rock, sediment, soil, mineral, and concentration sample media: U.S. Geological Survey Data Series 1117, 33 p., accessed January 24, 2020, at https://pubs.er.usgs.gov/publication/ds1117

International Association of Geoanalysts, 2019a, SdAR-L2 blended sediment (version 1): International Association of Geoanalysts Reference Material Data Sheet SdAR-L2, accessed January 22, 2020, at http://iageo.com/wp-content/ uploads/2020/03/SdAR-L2-RM-information-sheetrevision-2r.pdf

International Association of Geoanalysts, 2019b, SdAR-M2 metal-rich sediment (version 2): International Association of Geoanalysts Reference Material Data Sheet SdAR-M2 Version 2, accessed January 22, 2020, at http://iageo.com/ wp-content/uploads/2019/06/SdAR-M2-RM-informationsheet3-revision-2r.pdf

International Association of Geoanalysts, 2019c, SdARH1 metal-rich sediment: International Association of Geoanalysts Reference Material Data Sheet SdAR-H1 version 2, accessed January 22, 2020, at http:/iageo.com/ wp-content/uploads/2019/06/SdAR-H1-RM-informationsheet3-revision-2r.pdf

International Association of Geoanalysts, 2020, Homepage: International Association of Geoanalysts, web, accessed December 7, 2020, at www.geoanlyst.org

U.S. Geological Survey, 2015, Watershed boundary dataset (WBD): U.S. Geological Survey, web, accessed January 22, 2020 at https://www.usgs.gov/core-sciencesystems/ngp/national-hydrography/access-nationalhydrography-products 
Webb, P.C., Thompson, M., Potts, P., and Wilson, S.A., 2014, GeoPT35A-An international proficiency test for analytical geochemistry laboratories - Report on supplementary round 35A (Metalliferous sediment, SdAR-H1): International Association of Geoanalysts, accessed January 22, 2020, at http://www.geoanalyst.org/wp-content/uploads/2017/10/ GeoPT35AReport.pdf

Webb, P.C., Thompson, M., Potts, P., and Wilson, S.A., 2015a, GeoPT36A-An international proficiency test for analytical geochemistry laboratories - Report on round 36A (Metal-rich sediment, SdAR-M2): International Association of Geoanalysts, accessed January 22, 2020, at http://www.geoanalyst.org/wp-content/uploads/2017/10/ GeoPT36AReport.pdf
Webb, P.C., Thompson, M., Potts, P., and Wilson, S.A., 2015b, GeoPT37A-An international proficiency test for analytical geochemistry laboratories-Report on round 37A (Blended sediment, SdAR-L2): International Association of Geoanalysts, accessed January 22, 2020, http:/www.geoanalyst.org/wp-content/uploads/2017/10/ GeoPT37AReport.pdf 


\section{Appendix 1. Elemental Concentration Data for Archived Stream Sediment Samples from Alaska Reanalyzed in $\mathbf{2 0 1 9}$ and the Accompanying Standard Reference Materials}

Table 1.1. Elemental concentration data for the stream sediments analyzed in support of two U.S. Geological Survey projects-the statewide mineral prospectivity studies (W-focus data and Nixon Fork area-NF data) and a multidisciplinary study in southeast Alaska, here called the "transboundary watershed study" (TBW data).

[Table 1.1 is an Excel file that can be accessed at https://oi.org/10.3133/ofr20211058]

Table 1.2. Data from the quality control samples submitted with the archived stream sediments samples analyzed in support of the mineral prospectivity studies (W-focus data and Nixon Fork area-NF data) and a multidisciplinary study in southeast Alaska, here called the "transboundary watershed study" (TBW data).

[Table 1.2 is an Excel file that can be accessed at https://doi.org/10.3133/ofr20211058] 

Publishing support provided by the

U.S. Geological Survey Science Publishing Network, Tacoma Publishing Service Center

For more information concerning the research in this report, contact the

Director, Alaska Science Center

U.S. Geological Survey

4210 University Drive

Anchorage, Alaska 99508

https://www.usgs.gov/centers/asc/ 


\section{$\frac{\mathbb{2}}{3}$}

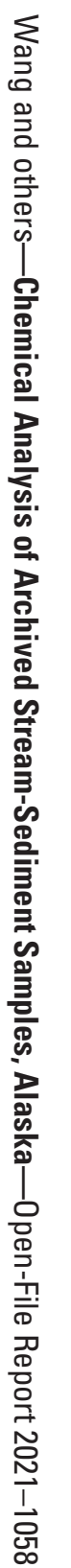

